\title{
Species-specific determinants of mortality and recruitment in the forest-steppe ecotone of northeast China
}

\author{
by Nan Zeng ${ }^{1}$, Huaxia Yao², Mei Zhou',", Pengwu Zhao ${ }^{1}$, Jeffrey P. Dech³ ${ }^{3}$ Bo Zhang ${ }^{1}$, Xue Lu$^{1}$
}

\begin{abstract}
Tree mortality is a notable phenomenon in the forest-steppe ecotone of China. However, the association between mortality and factors such as a changing climate is uncertain. In the summer of 2014 tree mortality was investigated in $20 \times 400$ $\mathrm{m}^{2}$ plots to determine the species-specific determinants of mortality and their influence on subsequent species recruitment. Nine soil physical-chemical properties were examined in addition to slope position, mean DBH and total number of trees. Generalized linear models analyzed relationships between these variables and mortality and recruitment. Mortality was positively associated with increasing average diameter and negatively to high soil $\mathrm{pH}$ and total nitrogen content. Recruitment models indicate that Populus davidiana recruitment was positively affected by available phosphorus and mortality, and negatively related to mean DBH. Slope position was the most important contributing variable to Betula platyphylla recruitment. With Quercus mongolica recruitment, soil variables played an important role. These results suggest that tree mortality is affected by soil properties, topography and tree size in China's forest-steppe ecotone, and may improve our understanding of species mortality and contribute to improved forest management.
\end{abstract}

Key words: tree mortality, forest-steppe ecotone, recruitment, broad-leaved forests

\begin{abstract}
RÉSUMÉ
La mortalité des arbres est un phénomène marquant dans lécotone de la steppe boisée de la Chine. Cependant, il n’est pas facile d'associer la concordance entre la mortalité et à divers facteurs comme les changements climatiques est incertaine. Au cours de lété lété 2014, nous avons examiné la mortalité des arbres a été étudiée dans desà laide de parcelles de $20 \mathrm{x}$ $400 \mathrm{~m}$ afin de déterminer les causes spécifiques de mortalité pour chaque espèceessence et leur influence sur le développement subséquent des espèceessences. Les analyses ont porté sur nNeuf propriétés physico-chimiques du sol ont été analysées, en plus de lemplacement selonla position sur la pente, le du dhp DHP moyen et le du nombre total d'arbres. On sest servi de Des modèles linéaires généralisés généraux ont servi à l’analyse despour analyser les relations entre ces variables et la mortalité et le recrutement. L’analyse a montré une corrélation positive avec la croissance en La mortalité était positivement associée à l'accroissement du diamètre moyen et négativement reliée à l'augmentation du pH du sol et du contenu en azote total. Les modèles de recrutement indiquent que le recrutement du Populus davidiana était lié au était positivement affecté par le phosphore disponible et à la mortalité, et négativement relié audiminuait avec le dhp DHP moyen. L’emplacement selonLa position sur la pente représentaite la variable la plus importante pour le recrutement du Betula platyphylla. Dans le cas du recrutement du Quercus mongolica, ce sont les variables du sol qui ont eu le plus d'influenceont joué un rôle déterminant. Ces résultats indiquent laissent voir que la mortalité des arbres dépend des propriétés du sol, de la topographie et de la taille des arbres dans le cas de lécotone de la steppe boisée de la Chine; ils et qu’ils pourraient améliorer notre compréhension de la mortalité des de chaque espèceessences et contribuer à améliorer bonifier l’aménagement forestier.
\end{abstract}

Mots clés : mortalité des arbres, écotone de la steppe boisée, recrutement, forêt feuillue

\section{Introduction}

Tree mortality in broad-leaved forests of China's forest-steppe ecotone is becoming an issue due to pressure from climate change (Liu et al. 2010, Dulamsuren et al. 2011, Kharuk et al. 2013). Under the stress of drought (Liu et al. 2013), species mortality and subsequent recruitment are more sensitive to environmental conditions (Laurance et al. 2001, Phillips et al. 2009). Environment-related tree mortality has been reported from several countries (Ferry et al. 2010, de Toledo et al. 2011, Redmond et al. 2015), however, there are no studies of species-specific determinants of mortality and recruitment at the plot-level in the forest-steppe ecotone in China.
Empirical studies have shown that unexpected tree mortality is a complicated natural event provoked by environmental factors such as inter- and intra- specific competition, pathogen and insect outbreaks, mechanical failure, and variable edaphic controls associated with differences in physiographic characteristics of landscapes (Koepke et al. 2010, de Toledo et al. 2011, Zeppe et al. 2011, Crosby et al. 2015). Demchik and Sharpe (2000) observed high species mortality in sample plots with low calcium-to-aluminum ratios in A and B soil horizons. Dorman et al.(2015) found that rapid infiltration of water, particularly in sandy soils, can cause the water to pool at deeper levels, making the water inaccessible

\footnotetext{
${ }^{1}$ College of Ecology and Environmental Science, Inner Mongolia Agricultural University, Hohhot, China 010010; ${ }^{*}$ corresponding author's e-mail: dxal528@aliyun.com

${ }^{2}$ Dorset Environmental Science Centre, Ontario Ministry of Environment and Climate Change, Ontario, Canada P0A 1E0

${ }^{3}$ Department of Biology, Faculty of Arts and Science, Nipissing University, Ontario, Canada P1B 8L7
} 


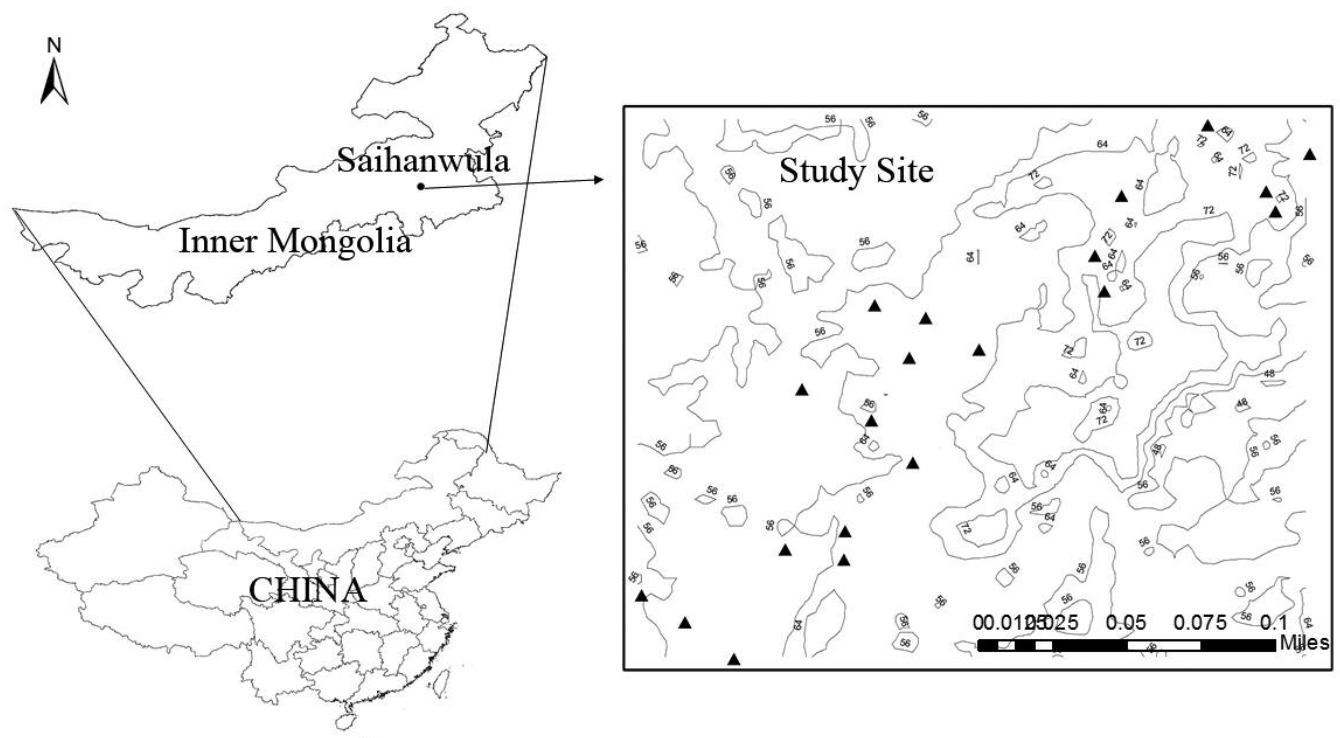

Fig. 1. Location map showing the study area and plots $[\mathbf{\Delta}$ ).

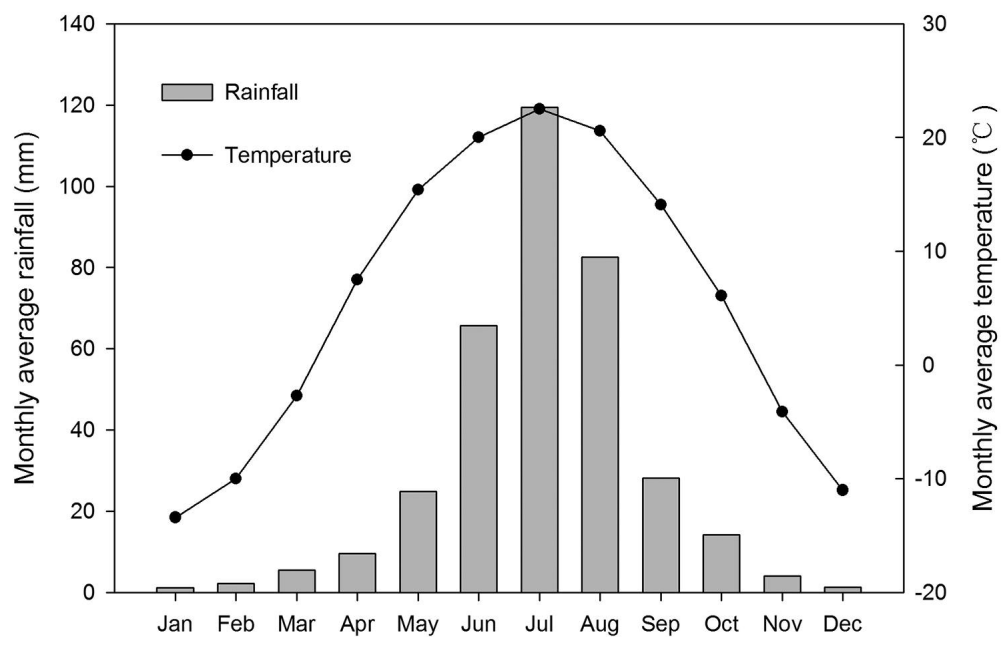

Fig. 2. Monthly meteorological data of the area during 1959-2012 mean DBH (diameter at breast height), and spatial patterns in plant communities (Simard et al. 2012). However, there does not appear to be a consistent suite of factors that could reliably predict patterns of mortality. High mortality rates were positively related to age and negatively related to density in planted stands of Pinus halepensis Miller (Dorman et al. 2015). This result does not support the commonly-held view that the probability of drought survival increases at lower stand densities, despite the assumption that levels of inter- and intra-specific competition and available resources are all improved with fewer trees in the stand. The effect of soil conditions on mortality may also be age-specific. In the state of Sarawak Malaysia, Hattori et al. (2013) found no significant relationship between seedling mortality and soil factors, including nutrient stocks (nitrogen, phosphorus, potassium, calcium, and magnesium) and water content. Previous research clearly showed site-specific fac-

to roots. Tree mortality rates increased in soils with low bulk densities and high $\mathrm{N}-\mathrm{NO}_{3}$ to $\mathrm{N}-\mathrm{NH}_{4}{ }^{+}$ratios (Corcobado et al. 2013). Low soil bulk density may help reduce the potential for soil compaction and adherence of roots (Cubera et al. 2009). In addition, high $\mathrm{N}-\mathrm{NO}_{3}{ }^{-}$to $\mathrm{N}-\mathrm{NH}_{4}{ }^{+}$ratios may be an indication of soil degradation (Wilson and Tilman 1991). On the other hand, Ferry et al. (2010) found that low mortality rates were typically found at the bottom of slopes, as bottomlands tend to provide more favorable growing conditions in terms of available water and temperature.

Other studies demonstrate an association between species mortality and forest structure such as stand density, stand age, tors influencing mortality and recruitment. These kinds of study, however, mostly focused on a single tree species. We hypothesize that a determinant of mortality and recruitment should be different for species with different ecological features (e.g., pioneer or climax species) in a mixed forest at the same time. To test this, local-scale heterogeneity in soil and topographical factors should also be included for a multi-variable statistical analysis.

In forest-steppe ecotones, massive recruitment has often occurred following unexpected tree mortality, leading to the replacement of the dominant species and turnover of the community (Kelly and Goulden 2008). For example, in the 
central Pyrenees of northeastern Spain, during an episode of drought-induced species mortality, abundant recruitment of Quercus spp. occurred which may lead eventually to the replacement of the currently dominant species Pinus sylvestris L. (Galiano et al. 2010). Although studies have analyzed mortality and subsequent species recruitment in several regions of the world, many factors potentially associated with species mortality still have yet to be examined in the forest-steppe ecotone of China. More observational experiments are needed to understand the bio-physical elements that control widespread tree mortality (Allen et al. 2010). Soil chemical properties (water content, $\mathrm{pH}$ and nutrient stocks) are extremely important factors in the forest-steppe ecotone, and which affect community composition, nutrient cycling and distribution of vegetation (Chytrý et al. 2008). Slope position may also influence species mortality as an important indirect factor, since microclimate and light conditions change with different slope positions (Ferry et al. 2010).

The goal of this study is to determine if soil chemical properties, slope position and two forest structural factors (mean $\mathrm{DBH}$ and total number of trees) are related to species mortality and recruitment, and to quantify these effects at the plotlevel. Three main questions were addressed in our study:

1) How is mortality and recruitment affected by diameter?

2) Since drought induced mortality is widespread in the forest-steppe ecotone, does soil water content play a role in plot-level tree mortality?

3) Can variations in mortality and community recruitment be explained by the factors selected?

\section{Material and Methods Site description}

The study was carried out in a broad-leaved forest dominated by Betula platyphylla Sukaczev, Populus davidiana L. and Quercus mongolica Fisch. ex Ledeb. in the Saihanwula Forest Ecosystem National Research Station $\left(118^{\circ} 18^{\prime}-118^{\circ} 55^{\prime} \mathrm{E}\right.$; $\left.43^{\circ} 59^{\prime}-44^{\circ} 27^{\prime} \mathrm{N}\right)$ located in the forest-steppe ecotone of the eastern region of Inner Mongolia, China (Fig. 1).

The climate is characterized by an annual mean temperature of $2^{\circ} \mathrm{C}$ and an annual accumulated precipitation of 358 mm (Weather Bureau of Bairin Right Banner, 2016), with a wet season from May to September. The highest rainfall (120 $\mathrm{mm})$ and temperatures $\left(23^{\circ} \mathrm{C}\right)$ occur in July (Fig. 2). Soil characteristics vary along an altitude gradient: grey forest soil, brown loam and dark chestnut soil are distributed at elevations of 1500-1900 m, 800-1400 m and 500-1200 m respectively. Soils are slightly acidic or near-neutral, and the topography has a mean elevation of $1000 \mathrm{~m}$, gradually lowering from northeast to southwest (Zeng et al. 2014).

\section{Field sampling}

In May to September 2014, 20 square plots (400 $\mathrm{m}^{2}$ each) were selected along a slope gradient based on the following criteria to avoid environmental heterogeneity: (i) no recent management or disturbance on the plots; (ii) the plots had the same aspect; and, (iii) plots were at least $50 \mathrm{~m}$ apart.

\section{Tree mortality and recruitment data}

For each plot, all trees $(\mathrm{DBH}>1 \mathrm{~cm})$ were identified and $\mathrm{DBH}$, height, state (alive or dead) and location in the plot were recorded. Latitude and longitude of plots were measured using a GPS. Diameter was measured to the nearest $1 \mathrm{~mm} 1.3$ $\mathrm{m}$ height above the ground (DBH). Mortality was recorded as the number of dead trees relative to the total number of trees (Galiano et al. 2010).

Five subplots ( $4 \mathrm{~m}^{2}$ each) were sampled in each plot for surveying recruitment. Species, quantity, mean height, basal stem diameter and coverage of every seedling were recorded for each of 105 subplots. The position of a plot on the slope was classified into five categories: bottom, footslope, backslope, shoulder and summit, with three to four plots within each category. Field survey work was conducted based on the "Forestry Standards: Observation Methodology for Longterm Forest Ecosystem Research" of People's Republic of China (Wang et al. 2011a, Wang et al. 2011b, Yu et al. 2013).

\section{Soil sampling}

Three soil samples were collected from each of four soil layers $(0-10 \mathrm{~cm}, 10-20 \mathrm{~cm}, 20-30 \mathrm{~cm}, 30-40 \mathrm{~cm})$ at the centre of each plot, and mixed to form one composite sample for each plot. Each sample was then separated into two sub-samples, one used to measure soil water content (SWC), the other to determine physical and chemical characteristics such as primary nutrients (nitrogen $(\mathrm{N})$, phosphorus $(\mathrm{P})$ and potassium $(\mathrm{K})$, soil organic matter $(\mathrm{OM})$ and $\mathrm{pH}$.

Sub-samples for SWC determination were weighed fresh before drying at $105^{\circ} \mathrm{C}$ for 24 hours. Gravimetric soil moisture was calculated as the percentage of water in the sample mass by weight. Sub-samples for physical and chemical properties were air-dried for 3-5 days, fine roots and stones removed, and the samples sieved ( $2 \mathrm{~mm}$ mesh) and stored in envelopes for analyzing $\mathrm{pH}$, available $\mathrm{N}(\mathrm{AN})$, available $\mathrm{P}$ (AP) and available $\mathrm{K}$ (AK). A portion of the $2 \mathrm{~mm}$-mesh samples were sieved further using a $0.25 \mathrm{~mm}$ mesh for analyzing $\mathrm{OM}$, total $\mathrm{N}(\mathrm{TN})$, total $\mathrm{P}(\mathrm{TP})$ and total $\mathrm{K}(\mathrm{TK})$.

Soil $\mathrm{pH}$ was measured using a $\mathrm{pH}$ meter (320P-01N, Thermo Orion, USA). The chemical oxidation of potassium dichromate $\left(\mathrm{K}_{2} \mathrm{Cr}_{2} \mathrm{O}_{7}\right)$ process was used to determinate OM. A $5-\mathrm{ml}$ solution of concentrated sulfuric acid, $5 \mathrm{ml}$ of $\mathrm{K}_{2} \mathrm{Cr}_{2} \mathrm{O}_{7}$ and soil samples were heated to $180^{\circ} \mathrm{C}$, boiled for five minutes, and titrated with ferrous ammonium sulfate solution until the color changed to turbid blue. TN was measured by Kjeldahl nitrogen analyzer (KDY-9830, China). A spectrophotometer was used to determine TP and AP and a flame photometer (FP640, China) to determine TK and AK. All methods for determining soil properties were conducted according to Bao (1999).

\section{Statistical analyses}

Models were fitted to determine if measured or derived factors could explain the spatial variation in species mortality and recruitment. Species mortality was derived from dividing the number of dead trees in each diameter class by the total number of trees in that class. Nine soil variables (SWC, $\mathrm{pH}$, OM, TN, TP, TK, AN, AP, AK), two forest stand variables (mean $\mathrm{DBH}$ and total number of trees) and one topography variable (slope position) were introduced into the mortality and recruitment models as explanatory variables. Species mortality was introduced into the three species recruitment models as one of the explanatory variables. Some of these variables did not comply with normal distribution after standard transformations; therefore, generalized linear models were used to analyze the relationship between selected factors and species mortality or recruitment (Galiano et al. 2010). 
(a) Populus davidiana

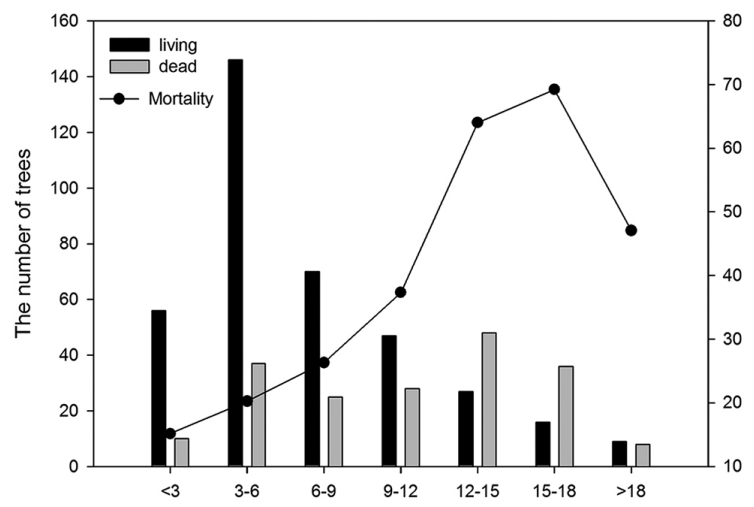

(c) Quercus mongolica

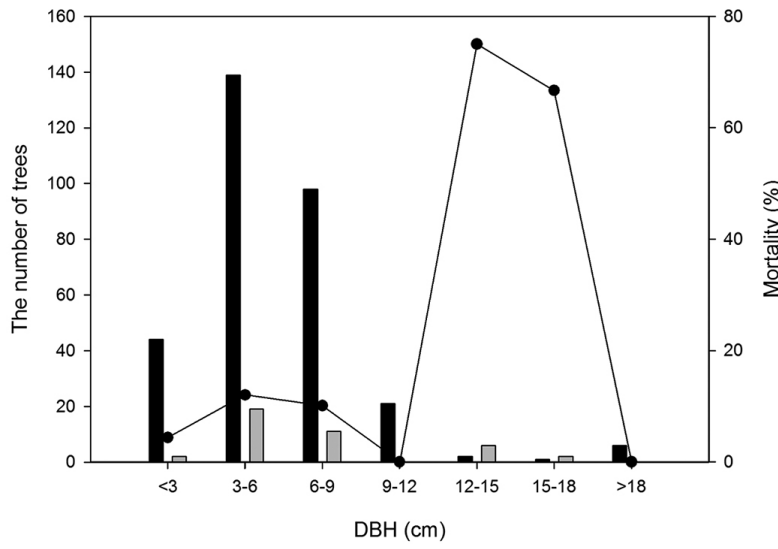

(b) Betula platyphylla

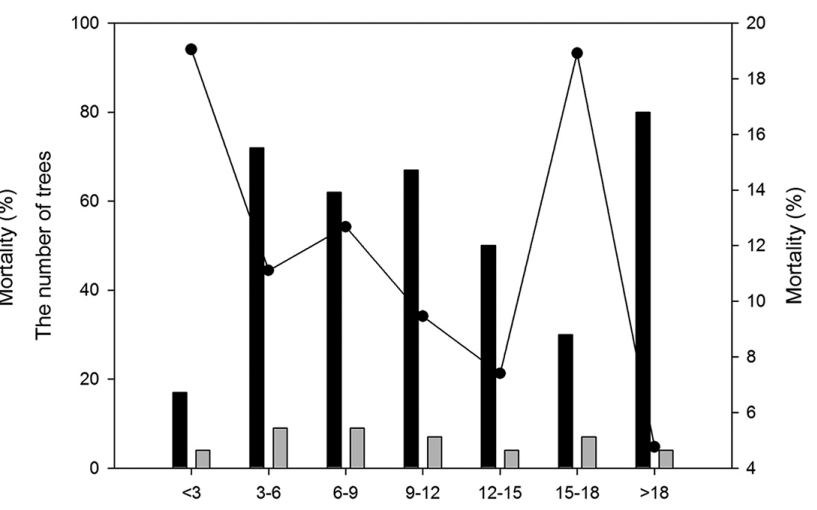

(d) All species

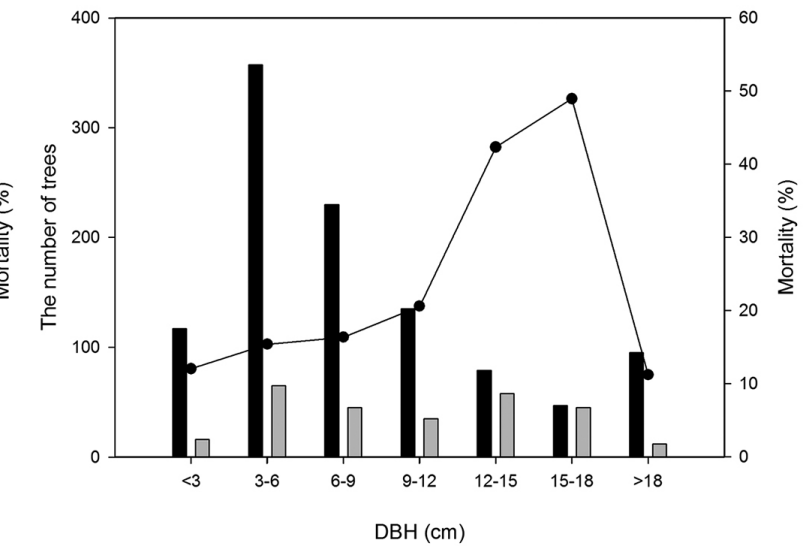

Fig. 3. Number of living and dead trees in different $\mathrm{DBH}$ classes

A stepwise selection method was used for model fitting, and began with all original explanatories and eliminating one variable at a time based on Akaike information criterion (Akaike 1974). At each step, the model was improved by adding back an explanatory variable which had been removed at a previous step. The final models here represent the most sparing fit achieved. The marginal $\mathrm{R}^{2}$ describes the proportion of variance explained by the fixed factors alone, and the conditional $\mathrm{R}^{2}$ the proportion of variance explained by both fixed and random factors (Araujo Calçada et al. 2015). Parameter $\beta$ is the unknown model parameter and was estimated by a maximum likelihood method. Spearman correlation coefficients were used to measure the correlation between pairs of variables. All calculations and statistical analyses used the R software ( $\mathrm{R}$ Development Core Team 2013).

\section{Results}

Species-specific determinants of mortality and recruitment $P$. davidiana had the highest mortality, followed by $B$. platyphylla and Q. mongolica (Fig. 3). The number of live trees of $P$. davidiana, Q. mongolica and all species combined peaked in the smallest diameter class (3-6 cm; Fig. 3). P. davidiana showed the highest mortality (69.2\%) between DBH 15-18 $\mathrm{cm}$ (Fig. 3a). In contrast, Q. mongolica had lower mortality, with no dead trees in diameters 9-12 cm and $>18 \mathrm{~cm}$ (Fig. 3c). The lowest mortality of P. davidiana (15.2\%) was in the smallest diameter class $(<3 \mathrm{~cm})$; a parabolic mortality trend was displayed across diameter classes for this species (Fig. 3a). Mortality of B. platyphylla showed no clear trend across DBH classes and was generally low across the range of diameters. Mortality of this species peaked (19.1\%) below $3 \mathrm{~cm} \mathrm{DBH}$ and was lowest (4.8\%) in the highest class ( $>18 \mathrm{~cm}$; Fig. 3b). Overall, mortality was lowest for Q. mongolica, and actually zero for DBH classes 9-12 cm and $>18 \mathrm{~cm}$ (Fig. 3c).

The bottom of the slope had the largest number of live trees (Fig. 4). Mortality tended to be the highest (24.5\%) on the slope shoulders (Fig. 4); however, this was largely due to high mortality of $P$. davidiana in this position. The other species had peak mortality on the lower slope (bottom and footslope). There were no clear trends in mortality across the slope gradient. The highest number of $Q$. mongolica seedlings appeared on the footslope, whereas the most $P$. davidiana seedlings appeared on the shoulder (Fig. 5). The number of $B$. platyphylla seedlings tended to become higher along the slope gradient with the exception of the shoulder (Fig. 5). 

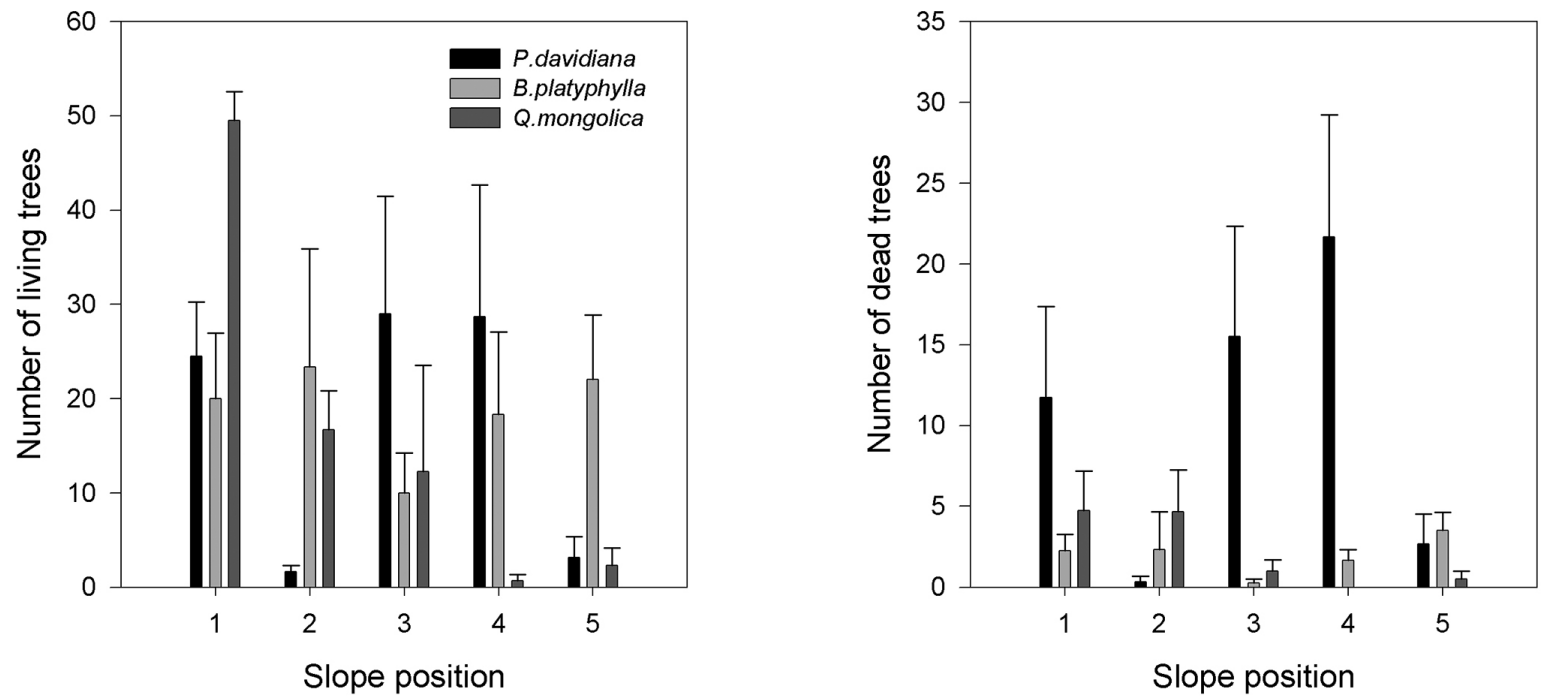

Fig. 4. Number of living and dead trees along the slope. Error bars show standard errors. 1 (bottom), 2 (footslope), 3 (backslope), 4 (shoulder) and 5 (summit).

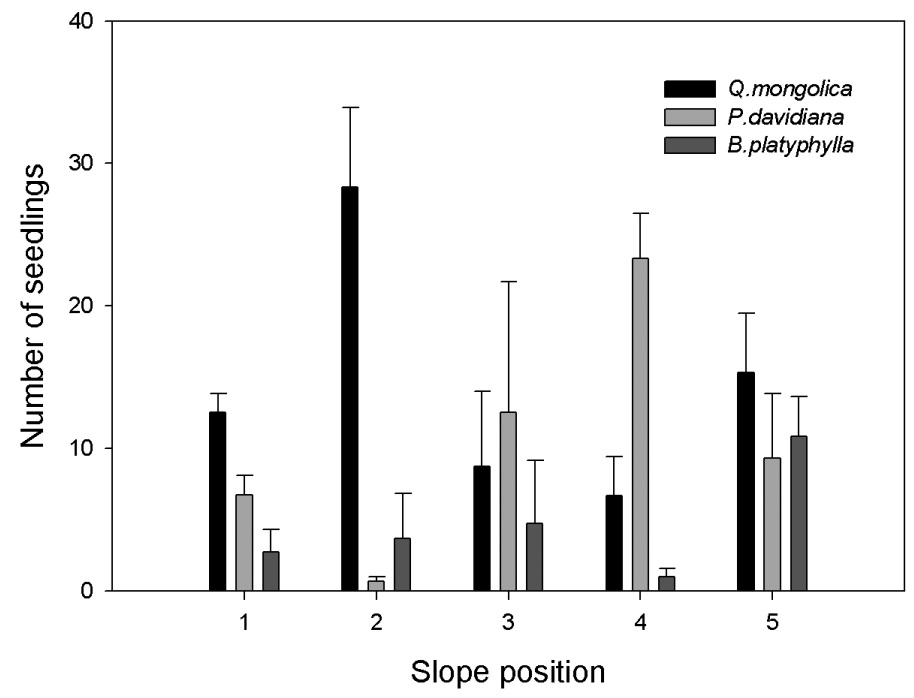

Fig. 5. Number of seedlings along the slope. Error bars show standard errors. 1 (bottom), 2 (footslope), 3 (backslope), 4 (shoulder) and 5 (summit).
There was also a significantly positive relationship between AP (available phosphorous) and mortality $(\beta>0, \mathrm{p}=0.003)$. Available $\mathrm{N}$ was also retained in this model and positively correlated with mortality, although this relationship was weaker $(\beta>0, p=0.05)$ than the other predictors (Table 1 ).

\section{Determinants of spatial variation of recruitment}

Based on the results of stepwise model selection, SWC, TN, TP, AK and slope position were removed from the recruitment model of $P$. davidiana (Table 2). Apparently recruitment was not controlled by a linear response to the gradient of slope position (Fig. 5). The most significant relationships detected in the model recruitment were positive associations with available $\mathrm{P}$ and mortality $(\beta>$ $0, \mathrm{p}=0.0001)$, and a negative association with mean $\mathrm{DBH}(\beta<0, \mathrm{p}=0.0001)$. The next most important variable selected indicated a strong negative relationship between the total number of trees and $P$. davidiana recruitment $(\beta<0, p=0.004)$. Other significant explanatory variables included positive relationships to OM (organic matter) content, and negative relationships with TK (total potassium) and AN. There was a positive and marginally significant relationship between $\mathrm{pH}$ and $P$. davidiana recruitment $(\beta>0$, $\mathrm{p}=0.079$ ), therefore $\mathrm{pH}$ was not removed from the model.

Six explanatory variables (TN, TP, TK, AN, AP and total number of trees) were removed from the model of B. platyphylla recruitment. Slope position was retained in this model 
Table 1. The generalized linear model for tree mortality

\begin{tabular}{llccc}
\hline $\begin{array}{l}\text { Response } \\
\text { variables }\end{array}$ & $\begin{array}{l}\text { Explanatory } \\
\text { variables }\end{array}$ & $\boldsymbol{\beta}$ & $\begin{array}{c}\text { Std. } \\
\text { Error }\end{array}$ & p-value \\
\hline Tree mortality & $\mathrm{pH}$ & -0.3484 & 0.0744 & $<0.001^{* * *}$ \\
& Total nitrogen & -0.1914 & 0.0301 & $<0.001^{* * *}$ \\
& Available nitrogen & 0.0006 & 0.0003 & 0.050 \\
& Available phosphorus & 0.0238 & 0.0078 & $0.003^{* *}$ \\
& Mean DBH & 0.0293 & 0.0076 & $<0.001^{* * *}$
\end{tabular}

Degrees of freedom $=79 ; A I C=-86.421 ;$ Marginal $R^{2}=0.53 ;$ conditional $R^{2}=0.53$.

Table 2. Generalized linear models for recruitment in different species

\begin{tabular}{|c|c|c|c|c|}
\hline $\begin{array}{l}\text { Response } \\
\text { variables }\end{array}$ & $\begin{array}{l}\text { Explanatory } \\
\text { variables }\end{array}$ & $\beta$ & $\begin{array}{l}\text { Std. } \\
\text { Error }\end{array}$ & p-value \\
\hline \multirow[t]{8}{*}{ P. davidiana } & $\mathrm{pH}$ & 6.0729 & 3.4074 & 0.079 \\
\hline & Organic matter & 0.8479 & 0.3789 & $0.028^{\star}$ \\
\hline & Total potassium & -0.5438 & 0.2136 & $0.013^{\star}$ \\
\hline & Available nitrogen & -0.0262 & 0.0117 & $0.028^{\star}$ \\
\hline & Available phosphorus & 1.5842 & 0.3171 & $<0.001^{\star * *}$ \\
\hline & Mortality & 47.6431 & 4.1254 & $<0.001^{\star * *}$ \\
\hline & Mean DBH & -1.3386 & 0.3726 & $<0.001^{\star * *}$ \\
\hline & Total number of trees & -0.0662 & 0.0222 & $0.004^{\star *}$ \\
\hline \multicolumn{5}{|c|}{ Marginal $R^{2}=0.79 ;$ conditional $R^{2}=0.79$. } \\
\hline \multirow[t]{7}{*}{ Betula platyphylla } & Soil water content & -0.6675 & 0.2913 & $0.025^{\star}$ \\
\hline & $\mathrm{pH}$ & 4.6038 & 3.1756 & 0.151 \\
\hline & Organic matter & -1.3573 & 0.4158 & $0.002^{* *}$ \\
\hline & Available potassium & -0.0161 & 0.0114 & 0.163 \\
\hline & Mortality & -8.1641 & 3.8769 & $0.039^{*}$ \\
\hline & Mean DBH & 0.7501 & 0.2873 & $0.011^{\star}$ \\
\hline & Slope position & 1.4146 & 0.3609 & $<0.001^{\star * *}$ \\
\hline \multicolumn{5}{|c|}{ Marginal $R^{2}=0.40 ;$ conditional $R^{2}=0.40$. } \\
\hline \multirow[t]{8}{*}{ Q. mongolica } & Soil water content & 0.7782 & 0.4221 & 0.069 \\
\hline & Total phosphorus & -41.6668 & 11.1147 & $<0.001^{* * *}$ \\
\hline & Total potassium & 0.8676 & 0.2819 & $0.003^{\star *}$ \\
\hline & Available nitrogen & -0.0439 & 0.0145 & $0.003^{\star \star}$ \\
\hline & Available phosphorus & -1.6277 & 0.4061 & $<0.001^{\star * *}$ \\
\hline & Available potassium & 0.0566 & 0.0133 & $<0.001^{\star * *}$ \\
\hline & Total number of trees & 0.0524 & 0.0270 & 0.056 \\
\hline & Slope position & 0.9354 & 0.5543 & 0.096 \\
\hline
\end{tabular}

Marginal $R^{2}=0.54$; conditional $R^{2}=0.54$.

Degrees of freedom=79; $A I C_{P \text {. davidiana }}=504.34 ; A I C_{\text {Betula platyphylla }}=500.39 ; A I C_{Q \text {. mongolica }}=549.35$.

Five explanatory variables $(\mathrm{pH}, \mathrm{OM}, \mathrm{TN}$, mean $\mathrm{DBH}$ and mortality) were eliminated from the model of $Q$. mongolica recruitment, the only recruitment model that did not include these explanatory variables. In this model, soil variables played an important role, in particular TP, AP and AK ( $\mathrm{p}<$ 0.001), of which both TP and AP were negatively associated with seedling recruitment $(\beta<0)$ and AK was negatively associated $(\beta<0)$. Other notably contributing variables were TK and $\mathrm{AN}$, which were positively and negatively correlated with recruitment respectively $(\beta>0, \mathrm{p}=0.003 ; \beta<0, \mathrm{p}=0.003)$. Less important explanatory variables that were significant included SWC, total number of trees and slope position, all positively related with $Q$. mongolica recruitment $(\beta>0)$.

\section{Discussion \\ How is tree mortality and recruitment affected by diameter?}

Higher mortality occurred in larger $\mathrm{DBH}$ classes for P. davidiana and Q. mongolica. However, the mortality rate of $B$. platyphylla did not show a clear difference across diameter classes. This result is in agreement with observations of Osumi and Sakurai (2002), as B. platyphylla mortality tended to decrease with increasing diameter. This may be explained by the low shade tolerance of Betula spp. (Baleshta et al. 2015), which typically require canopy disturbance to promote growth of Betula spp. seedlings in the understory. The survival of $B$. platyphylla in diameter classes greater than $3 \mathrm{~cm}$ likely reflects greater access to light, indicating that canopy openings have released these seedlings in the understory. Other studies have reported the similar trend of increasing size along with decreasing density of overstory Betula spp. (Simard and Zimonick 2005).

The first and second highest mortality of B. platyphylla occurred in $12-15 \mathrm{~cm}$ and $15-18 \mathrm{~cm}$ diameter classes but mortality subsequently decreased in the $\otimes 18 \mathrm{~cm}$ DBH class. The trend of mortality to diameter was a threshold response of improved survival at diameters $\nabla 3 \mathrm{~cm}$ rather than a linear increase in mortality with diameter. These nonlinear results are not consistent with some previous studies (Brumelis et al.

as the highest contributing variable $(\mathrm{p}<0.001)$ and was positively associated with recruitment $(\beta>0)$. Recruitment tended to increase with slope increase; the highest number of seedlings was on the summit and lowest at the bottom (Fig. 5). B. platyphylla recruitment was significantly and negatively correlated with OM $(\mathrm{p}=0.002)$. Significant relationships were also found between B. platyphylla recruitment and SWC ( $\mathrm{p}=$ $0.025)$, mortality $(\mathrm{p}=0.039)$ and mean DBH $(\mathrm{p}=0.011)$. The association with mortality and SWC was negative $(\beta<0)$, whereas mean $\mathrm{DBH}$ was positively correlated with recruitment $(\beta>0)$. Both $\mathrm{pH}$ and $\mathrm{AK}$ were not significant variables in this model $(\mathrm{p}=0.151 ; \mathrm{p}=0.163)$.
2009, Luo and Chen 2011) which suggested that mortality increased with tree size linearly which has been attributed to increasing competition for below-ground soil resources and above-ground light (Canham et al. 2004). Galiano et al. (2010) concur with our findings; after increasing and reaching a peak threshold, mortality did not further increase in the largest DBH classes. de Toledo et al. (2011) considered that patterns of size-dependent mortality may be influenced by the range of tree size. Similar conclusions were shown by Chao et al. (2008) and Laurance et al. (2009).

In addition, our data indicated a substantial difference in mortality or recruitment associated with slope position: the 
slope shoulder had the greatest mortality and highest recruitment for $P$. davidiana, and the lowest recruitment for B. platyphylla and Q. mongolica. Royo and Knight (2012) also found that white ash on upper slopes had higher dieback than paired plots on the lower slope. Vanak et al. (2012) suggested that trees on the mid-slope were more likely to suffer mortality than those on the slope crest. Our results are in agreement with these reports, as the frequently deficient nutrient conditions on upper slopes may lead to elevated mortality and favorable light conditions on crests possibly decreases mortality. Recruitment of Q. mongolica and B. platyphylla seedlings decreased on the slope shoulder, possibly from competition between seedlings (Takahashi et al. 2010).

\section{Does soil water play a role in plot-level mortality?}

Unexpectedly, soil water did not improve the model's power for explaining mortality. This is in disagreement with Fensham et al. (2007) and Phillips et al. (2010) who proposed that tree death increased when soil moisture became less. In contrast to their results, Galiano et al. (2010) removed the topographic wetness index related to soil water content from their model of recruitment, possibly due to the relatively narrow range of sites they sampled which encompassed only slightly varying topographic conditions. Since only one-season measurement was undertaken at our site, which is definitely not enough to give a wide range of soil water changes, we would not suggest that SWC (as we measured it) did not play an important role in tree mortality. Our local result may be explained by the limited research/experiment scale. Responses of mortality to drought events, differentiated sensitivities and resilience of vegetation were reported to vary between local and regional scales (Yin et al. 2013). The relationship between water stress and tree mortality at the local scale is more complicated than at a regional scale. The combined influences of micro-environment, wood density and xylem hydraulic failure in individual trees would be more sensitive indicators of water stress and provide additional insights into mortality trends observed in our study (Barigah et al. 2013). Perhaps water stress in our sites had not reached the severe conditions and its insignificant influence on mortality could be hidden by other factors.

Mortality in our study decreased as the TN increased. To some extent, nitrogen addition caused increased growth in some trees, but nitrogen saturation also likely damaged some trees (Wallace et al. 2007). Available P was positively associated with mortality, and the increase of AP should improve stand productivity, leading to more intense or severe competition among trees and therefore higher mortality (Ferry et al. 2010). Demchik and Sharpe (2000) found that high mortality plots showed a lower $\mathrm{pH}$, a result in agreement with our data. Overall, it seems likely that the determinant of mortality is related to the spatial scale of the study, probably shifting depending on whether the data are local or regional. In our case, our local-scale data indicate that $\mathrm{pH}, \mathrm{TN}, \mathrm{AP}$ and mean $\mathrm{DBH}$ are the most important factors affecting mortality.

Can variations in mortality and community recruitment be explained by the factors selected?

Our results indicate that the factors selected do provide a better explanation of the variations of community recruitment (Table 2; $\mathrm{R}^{2}=0.79,0.40$ and 0.54 for three species respec- tively). Soil variables explained a large part of community recruitment, especially for Q. mongolica. A seven-year study demonstrated significant positive effects of total soil nitrogen and water content on relative recruitment (Hattori et al. 2013). However, Li et al. (2015) found that plant density of recruited saplings decreased with nitrogen concentration. The same variable may affect community recruitment by distinct direction and magnitude in different ambient conditions (climate, soil, and dominant tree species). The influence of heterogeneous soil properties on recruitment dynamics needs to be comprehensively analyzed by considering competition, plant-soil feedback and soil-climate interactions (Peters et al. 2010, Brandt et al. 2013).

Death of over-story trees may alter understory recruitment by changing light intensity and soil moisture conditions, leading to changes in species composition and density of seedlings (Castro et al. 2004). Therefore, mortality rate was introduced into the models of recruitment as an explanatory variable, and was positively associated with recruitment of $P$. davidiana and negatively with $B$. platyphylla. This $P$. davidiana observation may be explained by the over-story mortality creating favorable light conditions for the shade-intolerant P. davidiana seedlings (Sankey 2008). In contrast, B. platyphylla recruitment decreased with increased mortality, although it is also a shade-intolerant species. Three possible reasons for the unexpected result are: 1) the range of gap or opening formed from dead trees could be a crucial factor to seedling establishment. Gärtner et al. (2011) suggested that a partial canopy is able to protect seedlings from impacts of climate extremes; 2)at the stand level (several hectares), species recruitment was negatively influenced by shrub cover. Béland and Chicoine (2013) reported that yellow birch regeneration was mainly affected by shrub competition; dead trees also provide ideal conditions for establishment of shrubs, which may lead to competition among shrubs, and seedlings of $P$. davidiana and B. platyphylla; and, 3) some fungal pathogens were possibly concentrated in plots with high tree mortality. O'Hanlon-Manners et al. (2004) found that the recruitment of white birch was inhibited by emerging fungal pathogens.

In conclusion, the dynamic variations in tree mortality and recruitment in forest stands may be explained by considering multiple factors, including species, size, slope location, and a suite of soil characteristics. These results may contribute to improved forest management by forest practitioners.

\section{Acknowledgements}

This study was supported by the Science and Technology Planning Project of Inner Mongolia, China (20110527) and the National Natural Science Foundation of China (41530747). This paper was also supported by CFERN \& GENE Award Funds on Ecological Paper. The thoughtful comments of reviewers are appreciated.

\section{References}

Akaike, H. 1974. A new look at the statistical model identification. IEEE Transactions on Automatic Control 19:716-723.

Allen, C.D. et al. 2010. A global overview of drought and heatinduced tree mortality reveals emerging climate change risks for forests. Forest Ecol. Manage. 259: 660-684. doi:10.1016/j.foreco. 2009.09.001 
Araujo Calçada, E., J. Lenoir, J. Plue, L. S. Broeckx, D. ClossetKopp, M. Hermy and G. Decocq. 2015. Spatial patterns of waterdeposited seeds control plant species richness and composition in riparian forest landscapes. Landscape Ecol. 30: 2133-2146. doi:10.1007/s10980-015-0236-y

Baleshta, K. E., S. W. Simard and W. J. Roach. 2015. Effects of thinning paper birch on conifer productivity and understory plant diversity. Scand. J. Forest Res. 30: 699-709. doi:10.1080/02827581. 2015.1048715

Bao S. 1999. Soil Agricultural and chemical analyses. Chinese Agricultural Press (in Chinese).

Barigah, T. S., O. Charrier, M. Douris, M. Bonhomme, S. Herbette, T. Ameglio, R. Fichot, F. Brignolas and H. Cochard. 2013. Water stress-induced xylem hydraulic failure is a causal factor of tree mortality in beech and poplar. Ann. Bot. 112: 1431-1437. doi:10.1093/aob/mct204

Béland, M. and B. Chicoine. 2013. Tolerant hardwood natural regeneration 15 years after various silvicultural treatments on an industrial freehold of northwestern New Brunswick. Forest. Chron. 89: 512-524. doi:10.5558/tfc2013-092

Brandt, A. J., H. Kroon, H. L. Reynolds, J. H. Burns and W. Putten. 2013. Soil heterogeneity generated by plant-soil feedbacks has implications for species recruitment and coexistence. J. Ecol. 101: 277-286. doi:10.1111/1365-2745.12042

Brumelis, G. et al. 2009. Stand structure and spatial pattern of regeneration of Pinus sylvestris in a natural treed mire in Latvia. Silva Fennica 43, 767-781.

Canham, C.D., P. T. LePage and K. D. Coates. 2004. A neighborhood analysis of canopy tree competition: effects of shading versus crowding. Can. J. Forest Res. 34: 778-787. doi:10.1139/x03-232

Castro, J., R. Zamora, R., J. A. Hódar and J. M. Gómez. 2004. Seedling establishment of a boreal tree species (Pinus sylvestris) at its southernmost distribution limit: Consequences of being in a marginal Mediterranean habitat. J. Ecol. 92: 266-277.

Chao, K.-J., O. L. Phillips, E. Gloor, A. Monteagudo, A. TorresLezama and R. V. Martínez. 2008. Growth and wood density predict tree mortality in Amazon forests. J. Ecol. 96: 281-292. doi:10.1111/j.1365-2745.2007.01343.x

Chytrý, M. et al. 2008. Diversity of forest vegetation across a strong gradient of climatic continentality: Western Sayan Mountains, southern Siberia. Plant Ecol. 196: 61-83. doi:10.1007/s11258-0079335-4

Corcobado, T., A. Solla, M. A. Madeira and G. Moreno. 2013. Combined effects of soil properties and Phytophthora cinnamomi infections on Quercus ilex decline. Plant and Soil 373: 403-413. doi:10.1007/s11104-013-1804-Z

Crosby, M. K., Z. Fan, A. M. Spetich, D. T. Leininger and X. Fan. 2015. Early indications of drought impacts on forests in the southeastern United States. Forest. Chron. 91(04): 376-383, doi: $10.5558 / \mathrm{tfc} 2015-067$

Cubera, E., G. Moreno and A. Solla. 2009. Quercus ilex root growth in response to heterogeneous conditions of soil bulk density and soil NH4-N content. Soil Till. Res. 103: 16-22. doi:10.1016/j.still. 2008.09.002

Demchik, M.C. and W. E. Sharpe. 2000. The effect of soil nutrition, soil acidity and drought on northern red oak (Quercus rubra L.) growth and nutrition on Pennsylvania sites with high and low red oak mortality. Forest Ecol. Manage. 136: 199-207.

de Toledo, J. J., W. E. Magnusson, C. V. Castilho and H. E. M. Nascimento. 2011. How much variation in tree mortality is predicted by soil and topography in Central Amazonia? Forest Ecol. Manage. 262: 331-338. doi:10.1016/j.foreco.2011.03.039

Dorman, M., T. Svoray, A. Perevolotsky, Y. Moshe and D. Sarris. 2015. What determines tree mortality in dry environments? A multi-perspective approach. Ecol. Appl. 25: 1054-1071.

Dulamsuren, C., M. Hauck, H. H. Leuschner and C. Leuschner. 2011. Climate response of tree-ring width in Larix sibirica growing in the drought-stressed forest-steppe ecotone of northern Mongolia. Ann. For. Sci. 68: 275-282. doi:10.1007/s13595-011-0043-9

Fensham, R.J., R. J. Fairfax and N. Kenkel. 2007. Drought-related tree death of savanna eucalypts: Species susceptibility, soil conditions and root architecture. J. Veg. Sci. 18: 71-80.

Ferry, B., F. Morneau, J.-D. Bontemps, L. Blanc and V. Freycon. 2010. Higher treefall rates on slopes and waterlogged soils result in lower stand biomass and productivity in a tropical rain forest: Treefall and biomass in a tropical rain forest. J. Ecol. 98: 106-116. doi:10.1111/j.1365-2745.2009.01604.x

Galiano, L., J. Martínez-Vilalta and F. Lloret. 2010. Droughtinduced multifactor decline of scots pine in the Pyrenees and potential vegetation change by the expansion of co-occurring oak species. Ecosystems 13: 978-991. doi:10.1007/s10021-010-9368-8

Gärtner, S. M., V. J. Lieffers and S. E. Macdonald. 2011. Ecology and management of natural regeneration of white spruce in the boreal forest. Environ. Rev. 19: 461-478. doi:10.1139/a11-017

Hattori, D., T. Kenzo, N. Yamauchi, K. O. Irino, J. J. Kendawang, I. Ninomiya and K. Sakurai. 2013. Effects of environmental factors on growth and mortality of Parashorea macrophylla (Dipterocarpaceae) planted on slopes and valleys in a degraded tropical secondary forest in Sarawak, Malaysia. Soil Sci. Plant Nutr. 59: 218-228. doi:10.1080/00380768.2012.762895

Kelly, A. E. and M. L. Goulden. 2008. Rapid Shifts in Plant Distribution with Recent Climate Change. Proceedings of the National Academy of Sciences of the United States of America 105: 11823-11826.

Kharuk, V. I., K. J. Ranson, P. A. Oskorbin, S. T. Im and M. L. Dvinskaya. 2013. Climate induced birch mortality in Trans-Baikal lake region, Siberia. Forest Ecol. Manage. 289: 385-392. doi:10.1016/ j.foreco.2012.10.024

Koepke, D.F., T. E. Kolb and H. D. Adams. 2010. Variation in woody plant mortality and dieback from severe drought among soils, plant groups, and species within a northern Arizona ecotone. Oecologia 163, 1079-1090. doi:10.1007/s00442-010-1671-8

Laurance, S. G., W. F. Laurance, H. E. Nascimento, A. Andrade, P. M. Fearnside, E. R. Rebello and R. Condit. 2009. Long-term variation in Amazon forest dynamics. J. Veg. Sci. 20: 323-333.

Laurance, W.F., G. B. Williamson, P. Delamônica, A. Oliveira, T. E. Lovejoy, C. Gascon and L. Pohl. 2001. Effects of a strong drought on Amazonian forest fragments and edges. J. Trop. Ecol. 17: 771-785. Li, Q., Y. Song, G. Li, P. Yu, P. Wang and D. Zhou. 2015. Grasslegume mixtures impact soil N, species recruitment, and productivity in temperate steppe grassland. Plant Soil 394: 271-285. doi:10.1007/s11104-015-2525-2

Liu, H., Y. Yin, J. Zhu, F. Zhao and H. Wang. 2010. How did the forest respond to Holocene climate drying at the forest-steppe ecotone in northern China? Quatern. Int. 227: 46-52. doi:10.1016/ j.quaint.2010.05.003

Liu, H. et al. 2013. Rapid warming accelerates tree growth decline in semi-arid forests of Inner Asia. Global Change Biol. 19: 2500-2510. doi:10.1111/gcb.12217

Luo, Y. and H. Y. H. Chen. 2011. Competition, species interaction and ageing control tree mortality in boreal forests: Tree mortality in boreal forests. J. Ecol. 99: 1470-1480. doi:10.1111/j.1365-2745. 2011.01882.x

O'Hanlon-Manners, D.L. and P. M. Kotanen. 2004. Evidence that fungal pathogens inhibit recruitment of a shade-intolerant tree, white birch (Betula papyrifera), in understory habitats. Oecologia 140: 650-653. doi:10.1007/s00442-004-1625-0

Osumi, K. and S. Sakurai. 2002. The unstable fate of seedlings of the small-seeded pioneer tree species, Betula maximowicziana. Forest Ecol. Manage. 160: 85-95.

Peters, D. P. C., J. E. Herrick, H. C. Monger and H. Huang. 2010. Soil-vegetation-climate interactions in arid landscapes: Effects of the North American monsoon on grass recruitment. J. Arid Environ. Special Issue 74: 618-623. doi:10.1016/j.jaridenv.2009.09.015 
Phillips, O.L. et al. 2009. Drought sensitivity of the Amazon rainforest. Sci. 323: 1344-1347.

Phillips, O.L. et al. 2010. Drought-mortality relationships for tropical forests. New Phytol. 187: 631-646.

R Development Core Team. 2013. R: A language and environment for statistical computing. R Foundation for Statistical Computing, Vienna, Austria.

Redmond, M. D., N. S. Cobb, M. J. Clifford and N. N. Barger. 2015. Woodland recovery following drought-induced tree mortality across an environmental stress gradient. Glob. Change Bio. 21: 3685-3695. doi:10.1111/gcb.12976

Royo, A. A. and K. S. Knight. 2012. White ash (Fraxinus americana) decline and mortality: The role of site nutrition and stress history. Forest Ecol. Manage. 286: 8-15. doi:10.1016/j.foreco. 2012.08.049

Sankey, T.T. 2008. Learning from spatial variability: Aspen persistence in the Centennial Valley, Montana. Forest Ecol. Manage. 255: 1219-1225. doi:10.1016/j.foreco.2007.10.041

Simard, M., E. N. Powell, K. F. Raffa and M. G. Turner. 2012. What explains landscape patterns of tree mortality caused by bark beetle outbreaks in Greater Yellowstone? Landscape patterns of bark beetle outbreaks. Glob. Ecol. Biogeogr. 21: 556-567. doi:10.1111/j.14668238.2011.00710.x

Simard, S.W. and B. J. Zimonick. 2005. Neighborhood size effects on mortality, growth and crown morphology of paper birch. Forest Ecol. Manage. 214: 251-265. doi:10.1016/j.foreco.2005.04.009

Takahashi, K., K. Arii and M. J. Lechowicz. 2010. Codominance of Acer saccharum and Fagus grandifolia: The role of Fagus root sprouts along a slope gradient in an old-growth forest. J. Plant Res. 123: 665-674. doi:10.1007/s10265-010-0312-y

Vanak, A. T., G. Shannon, M. Thaker, B. Page, R. Grant and R. Slotow. 2012. Biocomplexity in large tree mortality: Interactions between elephant, fire and landscape in an African savanna. Ecography 35: 315-321. doi:10.1111/j.1600-0587.2011.07213.x
Wallace, Z. P., G. M. Lovett, J. E. Hart and B. Machona. 2007. Effects of nitrogen saturation on tree growth and death in a mixedoak forest. Forest Ecol. Manage. 243: 210-218. doi:10.1016/j.foreco. 2007.02.015

Wang, B., Y. Jiang, X. Wei, G. Zhao, H. Guo and X. Bai. 2011 a. Effects of forest type, stand age, and altitude on soil respiration in subtropical forests of China. Scand. J. Forest Res. 26: 40-47. doi:10.1080/02827581.2010.538082

Wang, Y., P. Yu, K.-H. Feger, X. Wei, G. Sun, M. Bonell, W. Xiong, S. Zhang and L. Xu. 2011b. Annual runoff and evapotranspiration of forestlands and non-forestlands in selected basins of the Loess Plateau of China. Ecohydrology 4: 277-287. doi:10.1002/eco.215

Weather Bureau of Bairin Right Banner. 2016. Meteorological dataset.

Wilson D. S. and D. Tilman.1991. Interactive effects of fertilization and disturbance on community structure and resource availability in an old-field plant community. Oecologia 88: 61-71.

Yin, Y., H. Liu, G. Liu, Q. Hao and H. Wang. 2013. Vegetation responses to mid-Holocene extreme drought events and subsequent long-term drought on the southeastern Inner Mongolian Plateau, China. Agr. Forest Meteorol. 178-179: 3-9. doi:10.1016/j.agrformet. 2012.10.005

Yu, M. and O. J. Sun. 2013. Effects of forest patch type and site on herb-layer vegetation in a temperate forest ecosystem. Forest Ecol. Manage. 300: 14-20. doi:10.1016/j.foreco.2012.12.039

Zeng N., M. Zhou, P. Zhao, J. Wei, X. Chen and Y. Shu. 2014. Spatial distribution pattern and interspecific relationship of broadleaved secondary forest in Southern Daxingan Mountains. J. Northeast Forest. Uni. 42(7): 36-39, 43. DOI:10.13759/j.cnki.dlxb.2014.07.009 (in Chinese)

Zeppe, J. B., H. D. Adams and W. R. L. Anderegg, 2011. Mechanistic causes of tree drought mortality: Recent results, unresolved questions and future research needs. New Phytol. 192: 800-803. doi:10.1111/j.1365-2486.2011.02516.x 